\title{
TREND ANALYSIS OF STREAMFLOW AND ITS RELATION TO RAINFALL IN THE LOWER TAMIRAPARANI SUB-BASIN OF TAMILNADU, INDIA
}

\author{
Martina IsABELla, M. ${ }^{*}$ - AmbUjAM, N. K. - SANTHANA KRISHNAN, P. T. \\ College of Engineering, Anna University, Chennai, Tamilnadu 600025, India \\ *Corresponding author \\ e-mail: isabella789@gmail.com \\ (Received $11^{\text {th }}$ Jul 2019; accepted $25^{\text {th }}$ Nov 2019)
}

\begin{abstract}
Trend analysis of streamflow and its linkages to rainfall can facilitate the development of water resource management plans for watersheds. The present study focuses on trends in observed streamflow of the lower Tamiraparani river sub-basin in Tamilnadu, India using Mann - Kendall test and Sen's slope estimator for a period of 30 years. From this analysis, both the annual streamflow, annual rainfall increased very marginally at the rate of $0.1799 \mathrm{~m}^{3} / \mathrm{s} / \mathrm{year}$ and $4.3741 \mathrm{~mm} / \mathrm{year}$, respectively. Similarly, in the northeast monsoon period, both the rainfall and streamflow were increased very minimally during the analysis period. However, the observations made during the southwest monsoon showed declining trends for most of the rainfall stations and no significant trend was observed for streamflow. The calculated Spearman's Rho correlation factor $(\rho)$ between rainfall and streamflow showed weak correlation during summer (0.26) and very strong correlation during northeast monsoon (0.83), strong correlation during southwest monsoon (0.53) and moderate correlation during winter (0.40). From this analysis, using Mann - Kendal test and Spearman's correlation it implies that other than precipitation and temperature, urbanization, watershed and ecological development of the catchment area could have also influenced the trends of streamflow.
\end{abstract}

Keywords: climate variables, climate change, hydrological environment, Mann - Kendal, Sen's slope

\section{Introduction}

Water is a vital element for both natural and artificial environments and it is provided by the rivers of the country offering life generating fuel to ecology (Islam and Sikder, 2012). Rainfall serves as one among the major sources of flow in the rivers while others include melting of glaciers, base flow from groundwater, return flow from agricultural areas etc. (Raghunath, 2006). Streamflow assessment plays a vital role in guiding the decision makers for better planning and providing accurate information towards the future research. Due to the climate change and anthropogenic activities, most rivers are altering their streamflows on a global scale and present rivers are under severe threats (Gautam and Acharya, 2012). So, it is vital to analyse the changing phenomenon of various climatic variables mainly rainfall and temperature. The work by Jayadas and Ambujam (2019) studied the trend patterns of rainfall in lower Vellar sub-basin in Tamil Nadu which indicated that there has been an early onset of monsoon in the last three decades. Jain and Kumar (2012) reviewed about the trend analysis of rainfall and temperature of many studies and explained about the estimation procedure of trend analysis and magnitude of trend by Mann - Kendal and Sen's slope estimator.

Mann - Kendal test is one of the best methods for rainfall and temperature trend analysis to study the impacts of climate change and Mann - Kendal test can be used as the best water management tool for proper watershed protection (Nouri, 2017). Palaniswami and Muthiah (2018) analysed the trends in annual, seasonal maximum and minimum temperature in the Vellar river basin in Tamilnadu and found out that there is 
a significantly increasing trend in the basin. Punyawardena and Premalal (2013) using the Mann - Kendal test in central Sri Lanka observed that there was increasing trend patterns in the very heavy rainfall data series. Chakraborty et al. (2013) observed there was decreasing trends in both annual and seasonal rainfall in the Seonath river basin and they estimated the decreased rainfall as $-13.8 \mathrm{~mm} /$ year for Bodala river basin and 0.1 $\mathrm{mm} /$ year in sigma station using Sen's slope estimator test. Chand et al. (2019) analysed the temperature trends in the river basin in Nepal and they observed that there were the highest warming trends in the summer season followed by winter, pre monsoon and post monsoon. It is well understood that globally there is an increasing pattern of trends in temperature and decreasing patterns in rainfall. In addition to this, the work done by Panda et al. (2013) on streamflow trends in the Mahanadi river basin, India, estimated that there was a declining rate of $3388 \times 106 /$ decade in the river which suggested the possible environmental measures for the protection of the river basin. Various research works (Yadav et al., 2014; Ahmad et al., 2015; Javari, 2017; John and Brema, 2018) highlighted the importance of Mann - Kendal and Sen's slope estimator to detect the trend and Magnitude of trends and outlined the effectiveness of the statistical tests in finding out the trend of rainfall, temperature and streamflow in several areas worldwide. Hydro-climatic conditions assessment at a larger regional scale may lead to the loss of the spatial information of the particular variable. Therefore, it is logical to analyse hydro climatic variables at a small scale rather than at larger scale. So the objective of the study is framed to analyse the trend patterns in the measured stream flow and rainfall at the sub-basin level. Also, to investigate the correlation of upstream catchment rainfall over the streamflow of the lower Tamiraparani sub-basin which is one among the subbasins of perennial Tamiraparani River basin in India.

\section{Materials and Methods}

\section{Study area}

The lower Tamiraparani sub-basin is one among the seven sub-basins of Tamiraparani river basin in Tamilnadu, India as shown in Fig. 1. The lower Tamiraparani sub-basin lies between geographic coordinates N. lat $8^{\circ} 26^{\prime} 53.14^{\prime \prime}$ to $9^{\circ} 12^{\prime} 00^{\prime \prime}$ and E. long $77^{\circ} 29^{\prime} 19.91^{\prime \prime}$ to $78^{\circ} 07^{\prime} 52.31^{\prime \prime}$. The entire sub-basin covers an area of about $1891.64 \mathrm{~km}^{2}$. Tamiraparani River originates from Agastya malai on the Western Ghats of India, at an altitude of about $2000 \mathrm{~m}$. River Tamiraparani has a number of tributaries named Servalar, Manimuttar, Gadananadhi, Pachaiyar and Chittar. The river flows towards north east initially and towards east in the middle and at the end it confluences with Bay of Bengal near Palaya Kayal as shown in Fig. 2. All the subbasins along with Lower Tamiraparani basin lies within the tropical monsoon zone. Among all the basins, lower Tamiraparani sub-basin has the highest concentration of population, about 45 percent of the entire basin population lives here. It covers almost 37 percent of the total command area of the entire basin (Report on Micro level Reappraisal study of Tamiraparani River basin, 2015). Based on the hydro meteorological features of the basin, the entire year is divided into two periods 1) Monsoon period from June to December and 2) Non-monsoon period spanning from January to May. The monsoon period of the sub-basin is further sub-divided into southwest monsoon period from June to September and northeast monsoon period from October to December. Similarly, the non-monsoon period is further sub-divided into winter period from January and February and summer period from March to May. For 
the rainfall trend analysis, Point rainfall from rain gauges maintained by PWD were used. There are totally 16 rain gauge stations available, out of these 13 rain gauge stations located upstream to the stream gauge station were considered for the analysis. As these stations influence the streamflow measured in the lower Tamiraparani subbasin, the rainfall data from these stations were considered based on availability and reliability as shown in Fig. 2. As per the PWD appraisal report, the maximum annual rainfall is $1237.2 \mathrm{~mm}$ and the minimum annual rainfall is $236.30 \mathrm{~mm}$ in the study area. There is a gauge station named Murappanadu in the lower Tamiraparani sub-basin to measure the streamflow variations in the river. In the entire river basin, there are a total of two weather stations to measure temperature, relative humidity, wind speed and solar radiation.

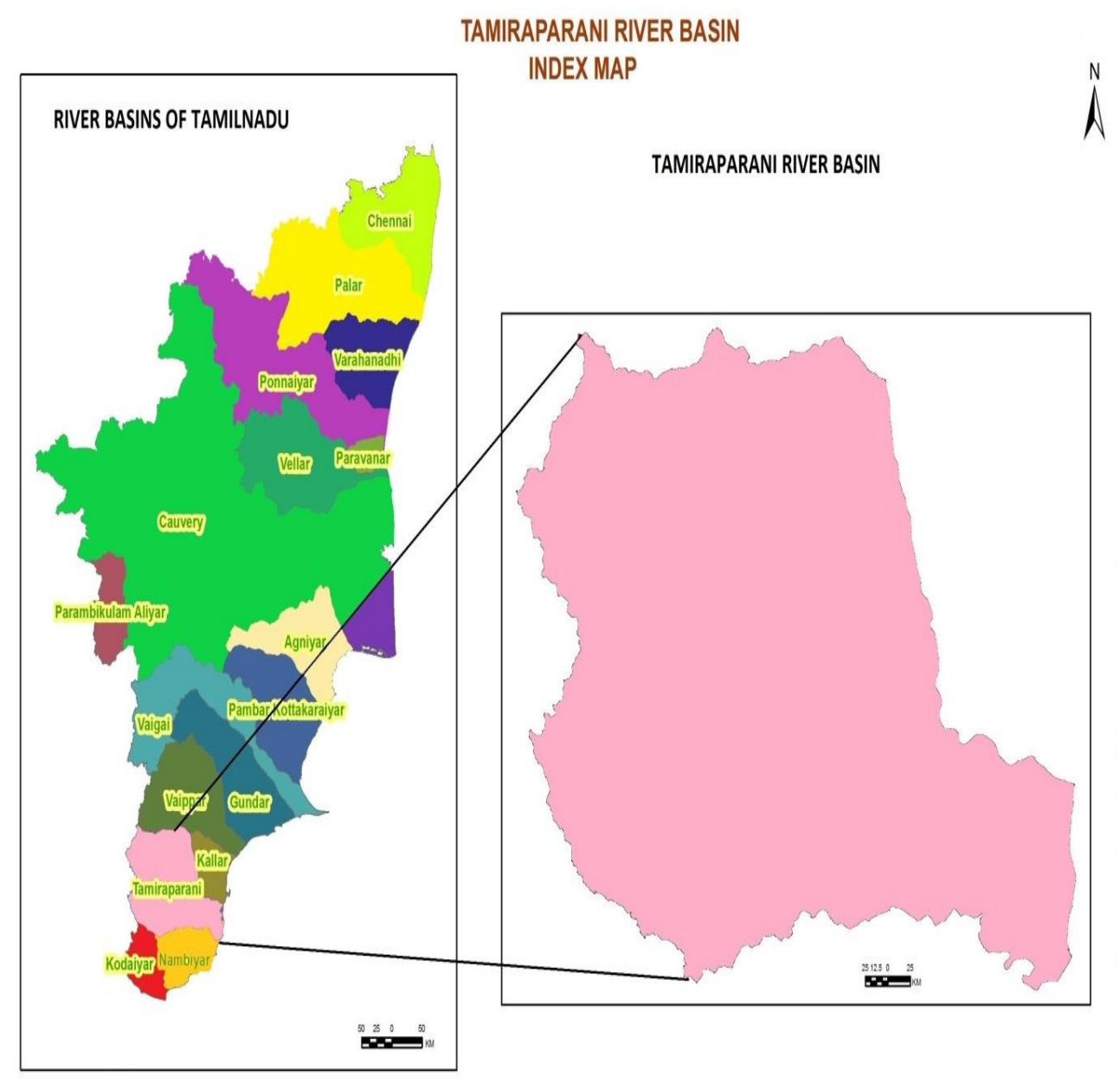

Figure 1. Index Map of Tamiraparani River basin

\section{Data set}

Streamflow data of the river were collected from the gauging station named Murappanadu as shown in Fig. 2, which is maintained by the Central Water Commission, Government of India. This is the nodal department in India to observe, calculate, quality check and archive all the hydrologic data of the river. All the meteorological parameters such as rainfall, wind speed and humidity and solar radiation were collected from the Institute of Water Studies, Public Works Department, and 
Tamil Nadu. Due to the insufficient availability of the observed temperature data, the temperature data was extracted from the gridded data collected from the Indian Meteorological department at the resolution of $1^{\circ *} 1^{\circ}$. The duration of the data sample collected was from 01-Jan-1985 to 31-Dec-2015. For the proper assessment of all climate change observations and to compare the spatial distribution of trend of streamflow and rainfall, it is normally necessary to have the sample duration of a minimum of 30 years of data. For the study, lower Tamiraparani river sub-basin is delineated using $30 \mathrm{~m}$ resolution ASTER data in ArcGIS 10.3. The total area of the subbasin is estimated to be $1891.64 \mathrm{~km}^{2}$. For the rainfall trend analysis, annual and seasonal rainfall from all influencing rain gauge stations contributing the streamflow in the study area from upper and middle reaches considered for the study as depicted in Fig. 2. The location details and period of data records of influencing and noninfluencing rain gauges considered are given in Table 1.

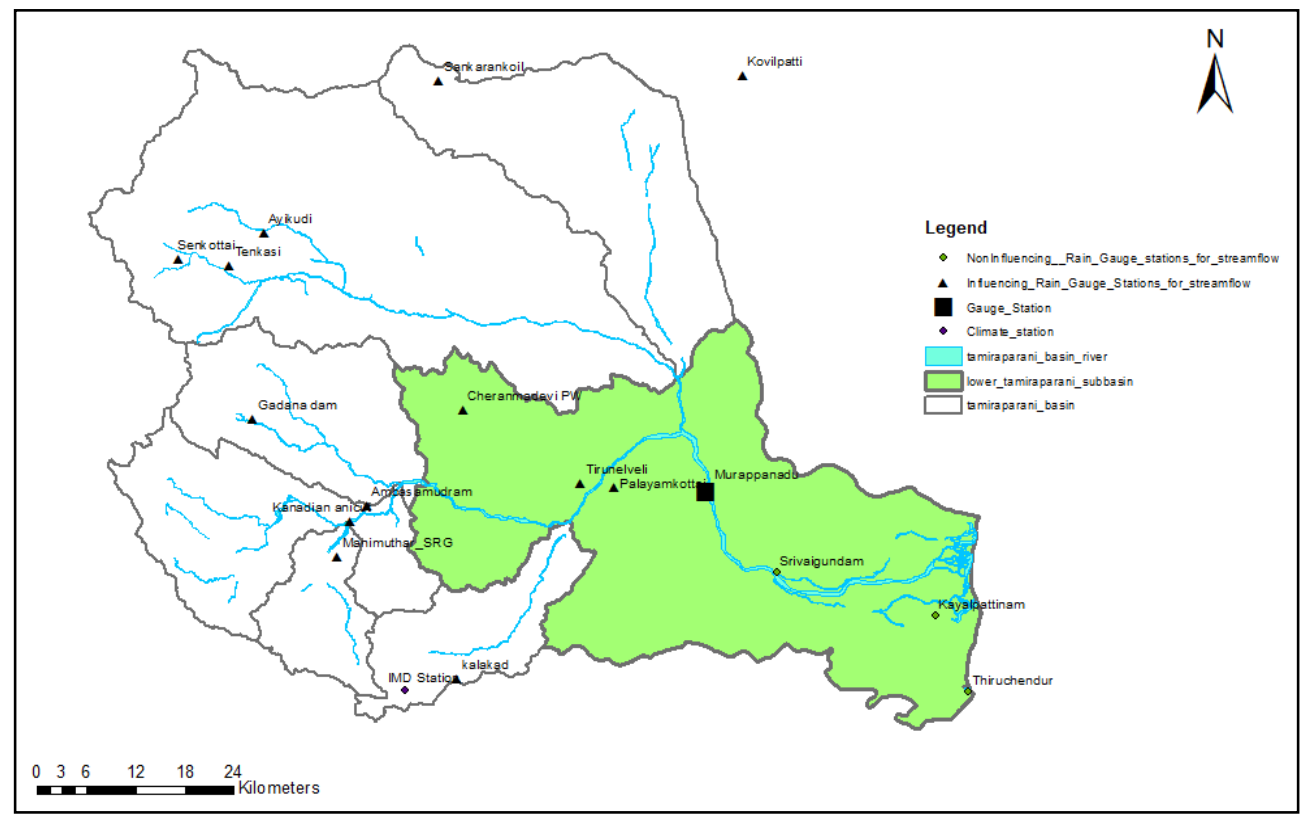

Figure 2. Geographical distribution of major stream network, streamflow gauging station and the influencing and non-influencing Rain gauge stations for streamflow of gauging station of Lower Tamiraparani sub-basin

\section{Analysis of data}

The following indicators were estimated and subjected to trend analysis.

- Inter - annual monthly mean streamflow which was calculated by estimating the monthly mean streamflow values for the same month of all the years.

- Annual mean streamflow which was estimated by taking the mean streamflow values for all the months of the gauging station.

- Seasonal mean streamflow, which was calculated by taking the mean of monthly streamflow values for summer, winter, northeast monsoon and southwest monsoon separately.

- Monthly maximum and minimum streamflows which were calculated by considering the maximum and minimum streamflow values recorded in a month for the gauging station. 
- Monthly and annual rainfall for all the rain gauges at the upstream of gauging station.

- Weighted annual, seasonal and monthly average rainfall for the rain gauges at upstream of the gauging station.

- Annual and seasonal maximum and minimum mean temperature for the weather station.

Theissen polygon method is one of the normally used methods in computing average rainfall for all hydrological studies. Through this theissen polygon method in the ArcGIS environment, the weights of each rain gauge stations were calculated with respect to the entire basin area and the annual and seasonal rainfall of the rain gauges which is at the upstream side of the gauge station was calculated.

Table 1. Geographical Coordinates and period of data records of the Rain Gauge stations

\begin{tabular}{|c|c|c|c|}
\hline Rain gauge station & Latitude & Longitude & Period of records \\
\hline Ambasamudram & $08^{\circ} 42^{\prime} 09^{\prime \prime} \mathrm{N}$ & $77^{\circ} 27^{\prime} 26^{\prime \prime} \mathrm{E}$ & $1985-2015$ (30 years) \\
\hline Ayikudi & $09^{\circ} 00^{\prime} 03^{\prime \prime} \mathrm{N}$ & $77^{\circ} 20^{\prime} 34^{\prime \prime} \mathrm{E}$ & $1985-2015$ ( 30 years $)$ \\
\hline Cheranmadevi & $08^{\circ} 41^{\prime} 17^{\prime \prime} \mathrm{N}$ & $77^{\circ} 33^{\prime} 49^{\prime \prime} \mathrm{E}$ & $1985-2015(30$ years $)$ \\
\hline Gadana dam & $08^{\circ} 47^{\prime} 46^{\prime \prime} \mathrm{N}$ & $77^{\circ} 19^{\prime} 53^{\prime \prime} \mathrm{E}$ & $1985-2015(30$ years $)$ \\
\hline Kalakadu & $08^{\circ} 30^{\prime} 48^{\prime \prime} \mathrm{N}$ & 77³3'27’'E & $1985-2015(30$ years $)$ \\
\hline Kanadian Anicut & $08^{\circ} 41^{\prime} 08^{\prime \prime} \mathrm{N}$ & $77^{\circ} 26^{\prime} 22^{\prime \prime} \mathrm{E}$ & $1985-2015(30$ years $)$ \\
\hline Kovilpatti & $09^{\circ} 10^{\prime} 27^{\prime \prime} \mathrm{N}$ & $77^{\circ} 52^{\prime} 28^{\prime \prime} \mathrm{E}$ & $1985-2015(30$ years $)$ \\
\hline Manimuthar & $08^{\circ} 38^{\prime} 45^{\prime \prime} \mathrm{N}$ & $77^{\circ} 25^{\prime} 32^{\prime \prime} \mathrm{E}$ & $1985-2015(30$ years $)$ \\
\hline Palayamkottai & $08^{\circ} 43^{\prime} 23^{\prime \prime} \mathrm{N}$ & $77^{\circ} 43^{\prime} 55^{\prime \prime} \mathrm{E}$ & $1985-2015$ (30 years) \\
\hline Sankarankoil & $09^{\circ} 10^{\prime} 04^{\prime \prime} \mathrm{N}$ & 77०32'12”'E & $1985-2015(30$ years $)$ \\
\hline Senkottai & $08^{\circ} 58^{\prime} 18^{\prime \prime} \mathrm{N}$ & $77^{\circ} 14^{\prime} 54^{\prime \prime} \mathrm{E}$ & $1985-2015(30$ years $)$ \\
\hline Tenkasi & $08^{\circ} 57^{\prime} 52^{\prime \prime} \mathrm{N}$ & $77^{\circ} 18^{\prime} 17^{\prime \prime} \mathrm{E}$ & $1985-2015(30$ years $)$ \\
\hline Tirunelveli & $08^{\circ} 43^{\prime} 40^{\prime \prime} \mathrm{N}$ & $77^{\circ} 41^{\prime} 41^{\prime \prime} \mathrm{E}$ & $1985-2015(30$ years $)$ \\
\hline Kayalpatinam* & $08^{\circ} 34^{\prime} 56^{\prime \prime} \mathrm{N}$ & 78 $05^{\circ} 19^{\prime \prime} \mathrm{E}$ & $1985-2015(30$ years $)$ \\
\hline Srivaigundam* & $08^{\circ} 37^{\prime} 45^{\prime \prime} \mathrm{N}$ & 77054'44”'E & $1985-2015$ (30 years) \\
\hline Tiruchendur* & $08^{\circ} 29^{\prime} 56^{\prime \prime} \mathrm{N}$ & 780'ㅇ'ㄹ & $1985-2015(30$ years $)$ \\
\hline
\end{tabular}

${ }^{*}$ Non-influencing rain gauge stations to the stream flow

\section{Statistical analysis}

While analyzing the trends in the data series, the monotonic trends of all the hydro climatic data series was tested using non parametric Mann - Kendall test using XLSTAT program. Initially all the time series data of the study were tested for lag one autocorrelation. If the time series data did not show any auto correlation, then Mann Kendall test was adopted for the trend analysis. If auto correlation was detected in the time series data then modified Mann - Kendall as suggested by Hamed-Rao using XLSTAT program should be used since Mann - Kendall test did not account for the serial auto correlation existing in the hydro -climatic series (Abeysingha et al., 2014). Then in order to compare the spatio-temporal variability between the rainfall and stream flow over the basin, the standardized anomaly was calculated for the time series data of both rainfall and streamflow. The standardized anomaly is calculated by subtracting the mean value of the data series from each observation and then divides the following with the standard deviation of the series. 


\section{Mann - Kendall test}

Monotonic trend analysis for rainfall, temperature and streamflow have been effectively done with non-parametric Mann - Kendall test in the studies (Mondal et al., 2012; Sharif et al., 2013; Silva et al., 2015). Mann - Kendall test is a statistical method which is being used for studying the variations of spatial regions and temporal trends of hydro climatic series. Mann - Kendall test had been formulated by Mann (1945) as nonparametric test for trend detection and the test statistic distribution had been given by Kendall (1955) for testing non-linear trend and turning point. Mann - Kendall test is a two tailed test. The test statistics $\mathrm{S}$ is calculated by

$$
\begin{gathered}
S=\sum_{\mathrm{i}=1}^{n-1} \sum_{j=i+1}^{n} \operatorname{sgn}\left(X_{j}-X_{\mathrm{i}}\right) x \\
\operatorname{sgn}\left(X_{j}-X_{\mathrm{i}}\right)\left\{\begin{array}{c}
1 \text { if }\left(X_{j}-X_{\mathrm{i}}\right)>0 \\
0 \text { if }\left(X_{j}-X_{\mathrm{i}}\right)=0 \\
-1 \text { if }\left(X_{j}-X_{\mathrm{i}}\right)<0
\end{array}\right. \\
\sigma^{2}=\frac{1}{18}\left[n(n-1)(2 n+5)-\sum_{p}^{q} t_{p}\left(t_{p}-1\right)\left(2 t_{p}+5\right)\right] \\
Z=\left\{\begin{array}{l}
\frac{S-1}{\sigma} \text { if } S>0, \\
\text { if } S=0, \\
\frac{S+1}{\sigma} \text { if } S<0 .
\end{array}\right.
\end{gathered}
$$

In the above equations $\mathrm{Xi}$ and $\mathrm{Xj}$ are the time series observations, $\mathrm{n}$ is the length of time series, $t \mathrm{p}$ is the number of ties for $\mathrm{pth}$ value and $\mathrm{q}$ is the number of tied values. The test hypothesis for Mann - Kendall analysis of trend is as follows:

- $\mathrm{H}_{\mathrm{o}}$ : There is no trend in the series.

- $\mathrm{H}_{\mathrm{a}}$ : There is a trend in the series.

Positive $\mathrm{Z}$ values indicate an increasing trend in the hydrologic time series and negative $\mathrm{Z}$ values indicate a decreasing trend. The statistic $\mathrm{Z}$ has a normal distribution. For testing the increasing or decreasing trend at $\alpha$ level of significance Ho was rejected if $|Z|>Z(1-\alpha / 2)$, where $Z(1-\alpha / 2)$ was obtained from the standard normal cumulative distribution.

\section{Sen's Slope estimator test}

Many research studies (Jayawardene et al., 2015; Samo et al., 2017; Gedefaw et al., 2018) estimated the magnitude of changing trends of the meteorological parameters well using Sen's slope estimator test. This test calculates both the slope and intercept using Sen's method (Sen, 1968). Initially a set of linear slope is calculated using

$$
T_{\mathrm{i}}=\frac{X_{j}-X_{k}}{j-k} \text { For } i=1,2,3 \ldots . N
$$


where, $X_{j}$ and $X_{k}$ are considered as data value at time $j$ and $k(j>k)$, respectively. The median of these $\mathrm{N}$ values of Ti is represented as Sen's estimator of slope which is given as:

$$
Q_{\mathrm{i}}=\left\{\begin{array}{c}
\frac{T_{N+1}}{2} N \text { is odd } \\
\frac{1}{2}\left(\frac{T_{N}}{2}+\frac{T_{N+1}}{2}\right) N \text { is even }
\end{array}\right.
$$

Positive value of $Q_{i}$ indicates upward or increasing trend and a negative value of $Q_{i}$ represents a presence of downward or decreasing trend in the time series of the data. Using the median based non-parametric slope estimator method suggested by Theil-Sen method (Theil, 1950). The magnitude of the trend is calculated using Equation 7

$$
\beta=\operatorname{median} \frac{x_{j}-x_{k}}{j-k} \ldots \forall \ldots k j
$$

where $X_{j}$ and $X_{k}$ are the consecutive data values of series in year $j$ and $k$, and $\beta$ is the magnitude of the trend slope of data values.

\section{Spearman's Rho correlation}

Then non-parametric Spearman's Rho correlation coefficient $(\rho)$ was used to test the relation between rainfall and streamflow. The Spearman's rank-order correlation is considered as the non-parametric method of the Pearson product-moment correlation. Spearman's Rho correlation coefficient, ( $\rho$, also signified by $r s$ ) estimates the strength and path of connotation between two ranked variables. Normally the co-efficient of Spearman's Rho correlation is calculated to determine the dependency rate of dependent variable which is streamflow in the river to the independent variable rainfall.

\section{Results and Discussions}

\section{Rainfall and stream flow behaviour of the lower Tamiraparani sub-basin}

To study the overall behaviour of the stream flow and rainfall of the influencing rain gauges, mean monthly stream flow and rainfall, annual streamflow and annual rainfall for the basin was calculated for the period of 30 years. Through the analysis, it was observed that both the maximum streamflow and maximum rainfall were observed during the month of November for most of the years. This indicates that almost all the rainfall occurring during November contributes to the streamflow of the river. In the lower Tamiraparani sub-basin bimodal rainfall pattern was observed, similar pattern was also observed in the streamflow of the river. The observed anomaly between the catchment rainfall and streamflow is depicted in Fig. 3. Both the annual mean streamflow and theissen weighted catchment rainfall of the basin showed no significant trends at both 5\% and 10\% level of significance as depicted in Table 2. The calculated Spearman's Rho correlation coefficient between two parameters showed that annual stream flow and annual rainfall have a very strong positive correlation existing between each other. The work observed in the river basin of Sri Lanka suggested that positive correlation between the annual rainfall and streamflow implied that annual mean streamflow of the river is mainly contributed by the catchment rainfall (Abeysingha et 
al., 2017). So in the lower Tamiraparani sub-basin the value of $(\rho=0.72)$ implied that streamflow is mainly contributed by the annual catchment rainfall from all influencing rain gauges from upper reaches of the gauge station. The results are in well agreement with the study by Sharannya et al. (2018), which also observed that changes in annual streamflow is directly correlated to the changes in annual rainfall for past and present scenarios.

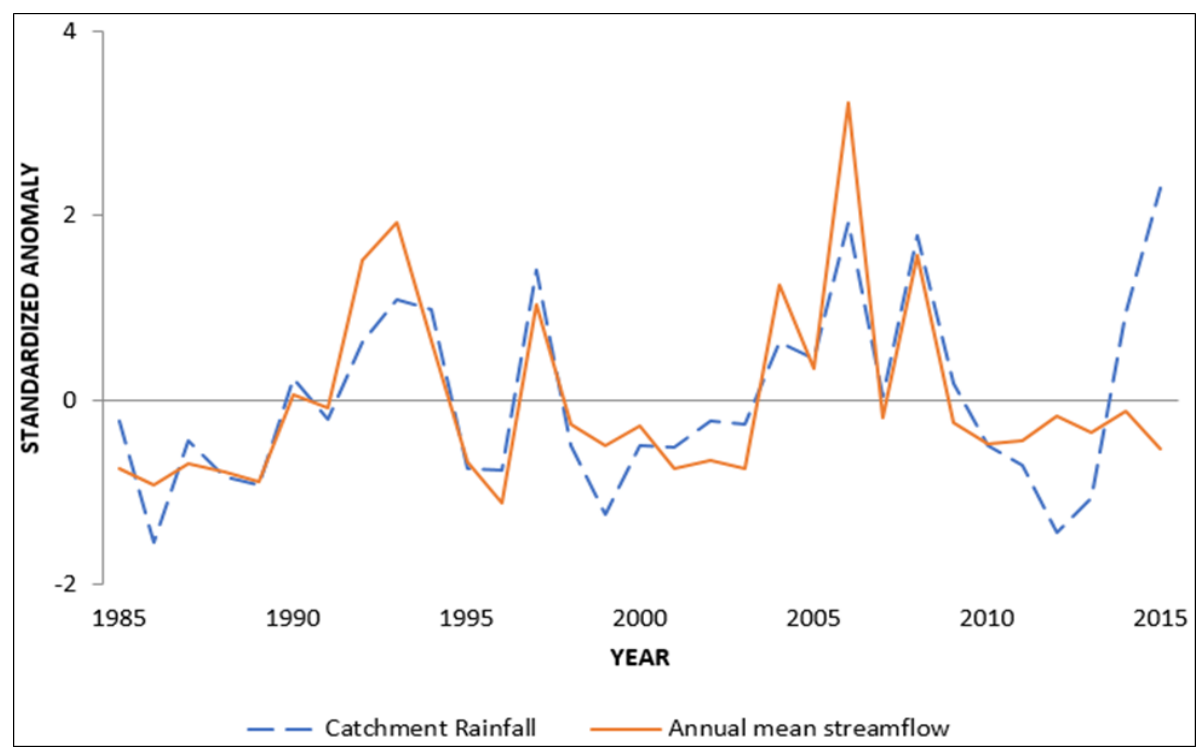

Figure 3. Temporal distribution of Standardized anomaly of catchment rainfall and annual mean stream flow for the period of 30 years

Table 2. Summarized results of Mann - Kendall test with Sen's slope estimator for annual mean streamflow and Catchment rainfall

\begin{tabular}{c|c|c}
\hline Sen's slope & Annual mean stream flow $\left(\mathbf{m}^{\mathbf{3}} / \mathbf{s}\right)$ & Catchment Rainfall(mm) \\
\hline $\mathrm{S}$ & 0.1799 & 4.3741 \\
\hline
\end{tabular}

\section{Trends in seasonal streamflow and seasonal rainfall}

Monotonic trends in streamflow and rainfall for the observed four seasons were analysed for the sub-basin and the Sen's slope estimator for all the seasons was calculated and given in Table 3 and 4. The calculated Sen's slope estimator for all the influencing rain gauges for all the seasons depicted that almost more than $50 \%$ of the influencing rain gauges showed no significant trends as depicted in Table 2. Most of the major river basins in northern India showed decreasing trends in the streamflow due to the decreasing of trends in rainfall and due to the anthropogenic activities in the basin level (Jain et al., 2017). However, the sub-basin level analysis of the study of the lower Tamiraparani showed marginally increasing trends in streamflow for all the seasons. While for the calculated weighted average seasonal rainfall, both the winter and southwest monsoon periods showed minimally declining trends, which is only of about $0.7477 \mathrm{~mm} /$ year and $1.1091 \mathrm{~mm} /$ year as depicted in Table 4. The observed rainfall trends during the southwest monsoon and winter periods showed a decreasing trend in the last 30 years of the study area, which is well linked with the trend analysis in the 
other major Indian river basin (Sharma and Singh, 2019). The calculated Spearman's rho correlation coefficient $(\rho=0.53)$ between the rainfall and streamflow in the southwest monsoon showed well correlation and during winter $(\rho=0.40)$ showed moderate correlation between the parameters as depicted in Table 5. In spite of the declining trends in the rainfall, minimal increase in streamflow implies that streamflow in lower Tamiraparani basin is not fully influenced by the rainfall during the periods instead partially influenced by others like anthropogenic activities which includes agricultural return flow, release water from hydro-electric power plant and rainfall in the upper hilly areas.

Table 3. Summarized results of Mann - Kendall test with Sen's slope estimator for seasonal rainfall ( $\mathrm{mm}$ ) of the influencing rain gauge stations of the streamflow in the sub-basin

\begin{tabular}{c|c|c|c|c}
\hline Rain Gauge Stations & Summer & Winter & Northeast & Southwest \\
\hline Ambasamudram & -0.009 & 0.0017 & 0.03 & -0.0243 \\
Ayikudi & 0.0183 & 0.0001 & 0.0791 & 0.0038 \\
Cheranmadevi & 0.0191 & 0.0035 & $0.0804^{* *}$ & -0.0009 \\
Gadana dam & -0.0187 & $-0.0442^{* *}$ & -0.0849 & -0.0224 \\
Kalakadu & 0.0053 & 0.0059 & 0.03 & -0.0131 \\
Kanadian Anicut & 0.0164 & 0.0122 & 0.034 & -0.0028 \\
Koilpatti & 0.0024 & $-0.029^{*}$ & -0.0016 & $-0.0403^{*}$ \\
Manimuthar & 0.0244 & 0.0429 & 0.1687 & -0.0048 \\
Palayamkottai & 0.0237 & -0.0117 & 0.0526 & -0.0017 \\
Sankarankoil & 0.0524 & -0.0009 & $0.0953^{*}$ & 0.0033 \\
Senkottai & 0.0131 & -0.0008 & 0.0842 & 0.0312 \\
Tenkasi & $0.0284^{*}$ & -0.0001 & 0.0511 & -0.0096 \\
Tirunelveli & -0.0119 & $-0.0199^{*}$ & 0.0128 & $-0.0217^{*}$ \\
\hline
\end{tabular}

* $-5 \%$ level of significance, ${ }^{* *}-10 \%$ level of significance

Table 4. Summarized results of Mann - Kendall test with Sen's slope estimator for seasonal mean stream flow (m3/sec/year) and weighted average seasonal rainfall (mm/year) for the stations

\begin{tabular}{c|c|c|c|c}
\hline Station & Summer & Winter & South West Monsoon & North East Monsoon \\
\hline Murappanadu & 0.0976 & 0.0778 & 0.0419 & 0.3337 \\
Influencing rain gauges & 1.1291 & -0.7477 & -1.1091 & 3.6938 \\
\hline
\end{tabular}

Table 5. Calculated Spearman's Rho Correlation Coefficient between rainfall and stream flow

\begin{tabular}{c|c|c|c|c}
\hline Seasons & Summer & Winter & Northeast & Southwest \\
\hline $\mathrm{P}$ & 0.26 & 0.40 & 0.82 & 0.53 \\
\hline
\end{tabular}

These observations were following the same pattern in the study of trend assessment (Nune et al., 2013) between the rainfall and stream flow in Himayat Sagar catchment in southern India in which they observed a change in stream flow without significant change in rainfall, and then they endorsed the changes in stream flow trends to anthropogenic influences in the particular catchment. The observed trends for the 
northeast monsoon for both streamflow and the rainfall showed minimal increase at a rate of $0.3337 \mathrm{~m}^{3} / \mathrm{sec}$ and $3.6938 \mathrm{~mm} /$ year but very strong positive correlation exists between the rainfall and stream flow $(\rho=0.82)$ during that period. The variation of the stream flow during North East Monson in the catchment is mainly attributed to the rainfall as evident by the significant positive correlation. The similar increasing trend pattern in the northeast monsoon rainfall was also observed in Amaravathi river basin one of the main river basins in Tamilnadu (Sridhar et al., 2017).

The observed trends between rainfall and stream flow during summer periods showed no significant trends which is of about $1.1291 \mathrm{~mm} / \mathrm{year}$ and $0.0976 \mathrm{~m}^{3} / \mathrm{sec}$ and also there was weak correlation $(\rho=0.26)$ between the rainfall and stream flow which implies that influence of rainfall to the streamflow is very minimum during the summer periods. Vidhya and Arulkumar (2017) predicted that there will be increase in streamflow up to the period of 2040 due to climate changes and decrease in streamflow will be observed with the combined effects of streamflow and climate changes which is well correlated with the present study with observed increasing trends in streamflow with the act of climate change. Then the observed decrease in the summer monsoon rainfall implied the weakening of westerlies in lower troposphere and formation of easterly jet stream in the upper troposphere as mentioned in the study for the Indian region (Naidu et al., 2009). In order to compare the spatio-temporal variability of the seasonal rainfall and streamflow, standardized anomaly was calculated and given in Fig. $4 a-d$ for all the seasons.

\section{Trends in monthly mean streamflow}

To study the monthly behaviour of streamflow in the river, trends using Mann Kendall test and Sen's slope were analysed for inter-annual monthly mean streamflow values as depicted in Table 6. Inter-annual monthly mean streamflow showed significantly positive trends for some of the months as quoted in the work carried out in the Gomati river basin which is the perennial river in Northern India (Abeysingha et al., 2016). The trend patterns of Tamiraparani streamflow also followed the same significantly increasing trends at $5 \%$ and $10 \%$ level of significance for the months of February, March, May, September, November and December. The significantly increasing trends of the following months September, November and December showed the influence of northeast monsoon rainfall to the streamflow in the sub-basin. For the months of February, March and May, the significantly increasing trends are due to the influence of climate change in the upper reaches of the sub-basin.

\section{Trends in monthly rainfall of the influencing rain gauge stations}

Monotonic trends for the inter-annual mean monthly rainfall for all the influencing stations of the streamflow in the sub-basin were analysed and it is shown in Table 7. From the results, mixed trend was observed for all the months for all the rain gauges for the lower Tamiraparani sub-basin but none were significant. For all the influencing rain gauges, no significant trends were observed for some of the months. During the month of February which is the winter season, very minimum change rate of rainfall was observed for all the rain gauges studied. In the study analysed by Arthi et al. (2014) no significant trends were observed for the weekly and monthly rainfall in the Coimbatore district of Tamilnadu. The similar pattern of no significant trend was also observed in the present study for the monthly rainfall pattern in all rain gauges of the sub-basin which covers the Tirunelveli and Thoothukudi districts of Tamilnadu. 

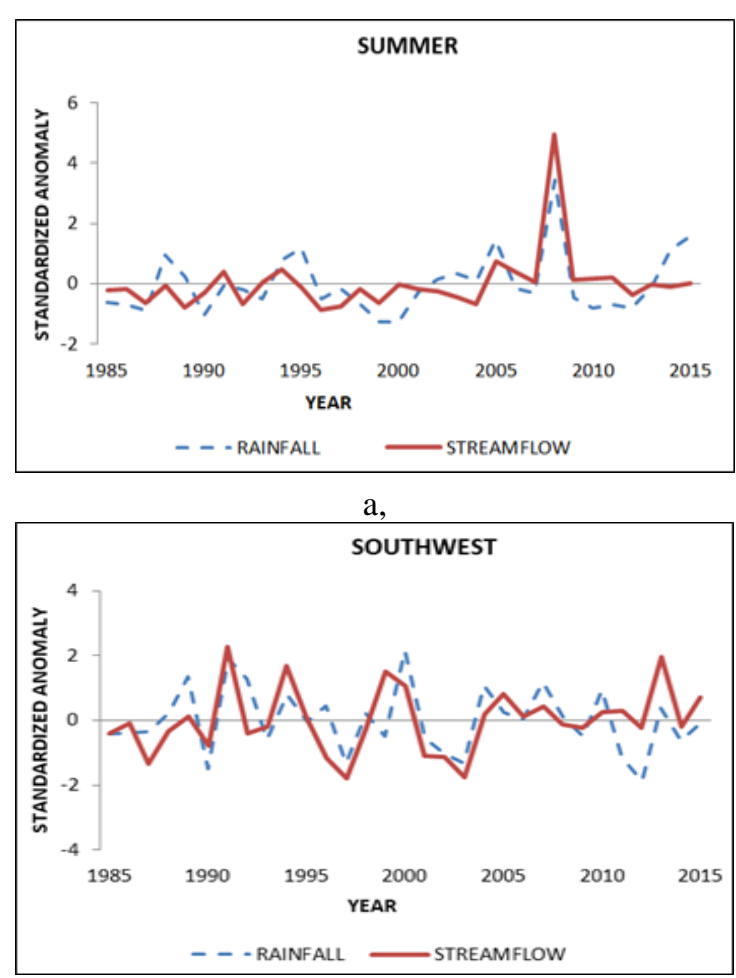

c,

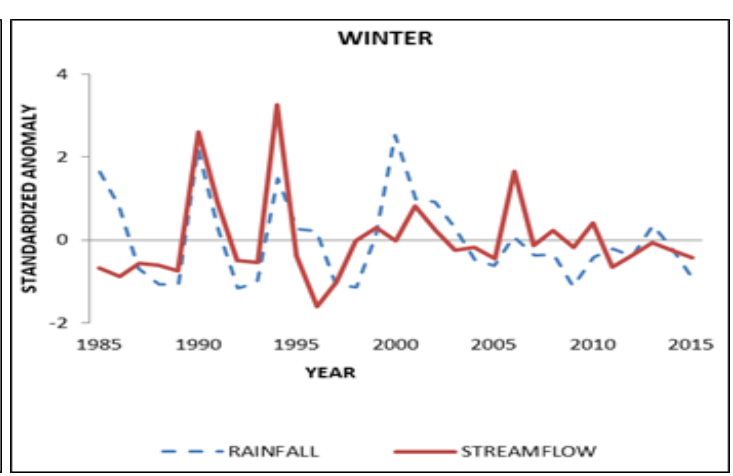

b,

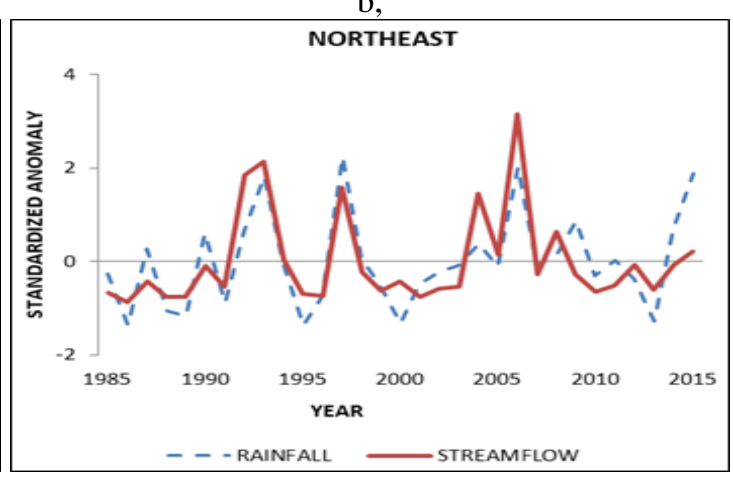

$\mathrm{d}$,

Figure 4. Temporal distribution of standardized anomalies of a: summer; $b$ : winter; $c$ : Southwest monsoon; $d$ : Northeast monsoon streamflow and rainfall for all influencing rain gauges

Table 6. Summarized results of Mann - Kendall test with Sen's slope estimator for mean monthly stream flow ( $\mathrm{m} 3 / \mathrm{sec} /$ year)

\begin{tabular}{c|c}
\hline Month & Mean monthly streamflow \\
\hline January & 0.0896 \\
February & $0.1568^{*}$ \\
March & $0.0969^{* *}$ \\
April & 0.0699 \\
May & 0.1332 \\
June & 0.0666 \\
July & 0.0899 \\
August & 0.0082 \\
September & $0.1104^{*}$ \\
October & 0.0443 \\
November & $0.6954^{* *}$ \\
December & $0.6043^{* *}$ \\
\hline
\end{tabular}

${ }^{*}-5 \%$ level of significance, ${ }^{* *}-10 \%$ level of significance

\section{Trends in temperature}

Table 8 showed the trends in annual, seasonal maximum and minimum temperature of the entire sub-basin for the study period. Annual temperature has increasing trends for both the maximum and minimum temperature. The results are well in agreement with the studies (Khavse et al., 2015; Ozgur et al., 2017), which analysed the long-term 
temperature trends for the periods of 100 years in the study and they identified increasing trends in annual temperature and decreasing trends in the monthly temperature. Zarenistanak (2014) analysed the trend patterns of temperature in Iran and they found non-significant trends in rainfall and significant trends in the temperature during summer and they observed that maximum temperature was more stable than minimum and mean temperature very precisely. The similar pattern was also observed in the present study with the stable increasing trends at a rate of $0.01{ }^{\circ} \mathrm{C} / \mathrm{year}$ in the maximum temperature while the minimum temperature showed no stable trends. In the seasonal analysis, both the seasonal maximum and minimum temperature showed no significant trends for all the seasons except southwest monsoon and winter season. During the northeast monsoon period, both maximum and minimum temperature showed marginal increase during the analysis. The summer period of the study area showed decrease in summer temperature at a minimal rate of $-0.0049^{\circ} \mathrm{C}$ and $-0.0062^{\circ} \mathrm{C}$ for both maximum and minimum temperature, respectively. However, in the southwest monsoon and winter, significantly increasing trend for maximum temperature is observed. Even a small change in the temperature can affect the agricultural patterns in the area largely (Sharma and Chaudhary, 2014). Since this sub-basin covers the majority of agricultural land use patterns, it is advisable to take appropriate measures to protect the crop yield by reducing the drying tendency especially during the southwest monsoon period and winter periods.

Table 7. Summarized results of Mann - Kendall test with Sen's slope estimator for Inter Annual monthly mean rainfall

\begin{tabular}{c|c|c|c|c|c|c|c|c|c|c|c|c}
\hline $\begin{array}{c}\text { Rain gauge } \\
\text { station }\end{array}$ & January & February & March & April & May & June & July & August & September & October & November & December \\
\hline Ambasamudram & -0.007 & 0.013 & 0.000 & -0.015 & -0.016 & -0.022 & -0.001 & -0.020 & 0.013 & 0.011 & 0.101 & 0.023 \\
Ayikudi & 0.002 & 0.001 & 0.022 & 0.040 & 0.001 & 0.018 & -0.003 & -0.004 & $0.0252^{*}$ & 0.083 & $0.185^{*}$ & 0.047 \\
Cheranmadevi & 0.004 & 0.000 & 0.007 & 0.025 & 0.016 & 0.000 & 0.000 & 0.000 & 0.001 & 0.059 & 0.182 & 0.019 \\
Gadana dam & -0.020 & 0.000 & -0.016 & -0.050 & -0.012 & -0.048 & -0.016 & -0.029 & 0.002 & -0.155 & -0.097 & -0.037 \\
Kalakadu & 0.000 & 0.000 & 0.007 & 0.021 & 0.003 & -0.020 & -0.017 & 0.005 & -0.005 & 0.018 & 0.143 & -0.006 \\
Kanadian Anicut & 0.000 & 0.000 & 0.008 & 0.003 & 0.000 & 0.000 & 0.001 & 0.006 & 0.001 & -0.046 & 0.077 & 0.058 \\
Koilpatti & 0.000 & 0.000 & -0.009 & -0.025 & 0.004 & 0.000 & -0.018 & 0.000 & -0.127 & -0.063 & 0.073 & -0.002 \\
Manimuthar & 0.007 & 0.032 & 0.027 & 0.002 & -0.007 & -0.018 & -0.005 & 0.001 & 0.019 & 0.154 & 0.178 & 0.135 \\
Palayamkottai & 0.005 & 0.000 & 0.000 & 0.039 & 0.004 & 0.000 & 0.001 & 0.010 & -0.010 & -0.013 & 0.166 & 0.013 \\
Sankarankoil & 0.000 & 0.000 & 0.016 & 0.081 & 0.011 & 0.000 & 0.001 & 0.002 & -0.004 & 0.047 & 0.257 & 0.024 \\
Senkottai & 0.000 & 0.000 & -0.008 & -0.013 & -0.047 & -0.035 & 0.030 & 0.012 & 0.087 & 0.041 & 0.143 & 0.046 \\
Tenkasi & 0.000 & 0.007 & 0.022 & 0.047 & -0.001 & -0.032 & -0.029 & -0.015 & 0.020 & 0.077 & 0.093 & 0.030 \\
Tirunelveli & $-0.0088^{* *}$ & 0.000 & -0.009 & 0.006 & -0.016 & 0.000 & 0.001 & 0.001 & -0.033 & -0.027 & 0.086 & -0.002 \\
\hline
\end{tabular}

$*-5 \%$ level of significance, ${ }^{* *}-10 \%$ level of significance

Table 8. Summarized results of Mann - Kendall test with Sen's slope estimator for annual and seasonal maximum and minimum temperature $\left({ }^{\circ}\right.$ Clyear $)$ of station in Lower Tamiraparani sub-basin

\begin{tabular}{c|c|c|c|c|c}
\hline Station & Annual & Summer & Winter & Southwest & Northeast \\
\hline Max & $0.01 *$ & -0.0049 & $0.0149 * *$ & $0.019^{*}$ & 0.004 \\
Min & 0.009 & -0.0062 & 0.0122 & 0.012 & 0.009 \\
\hline
\end{tabular}

* $-5 \%$ level of significance, ${ }^{* *}-10 \%$ level of significance 


\section{Conclusions and Recommendations}

The analysis on the annual, seasonal and mean monthly streamflow observed at the Murappanadu gauge station for the period of 30 years, which is in the lower Tamiraparani sub-basin showed that there is less drying tendency of the downstream catchments of the entire Tamiraparani river basin. The annual rainfall contributed mainly to the annual streamflow as evident by the positive correlation. The observed rainfall trends during the Southwest monsoon and winter periods showed a nominally declining trend in the last 30 years of the study area and slightly increasing trends during northeast and summer season. The present study mainly concluded that variation of streamflow in the basin is partly attributed by the rainfall during southwest monsoon and the variation of streamflow during the Northeast monsoon is mainly attributed by the rainfall during the analysis period with the calculated correlation coefficient. Since the study area lies in the downstream side of river, the marginal increase in the streamflow with the decrease in rainfall during the southwest monsoon and winter indicates that other factors such as anthropogenic activities and other exogenous and ecological changes may contribute to changes in streamflow in the downstream areas. Decrease in rainfall and increase in temperature during these periods suggests that proper management measures ought to be adopted to avoid the detrimental effects of drying tendency of the area to provide proper agricultural production and ecosystem sustainability in the future. These sub-basin level seasonal observations from the present study are thus helpful in developing the holistic water management planning within the sub - basin particularly during the southwest monsoon and winter by taking the managemental practices at different spatial scales based on the needs, which may be useful to conserve the water to meet the demands in the drying trends by increasing water use efficiency of the river water in various sectors of the hydrological environment. From those observations, it is further recommended to carry out detailed analysis of rainfall, temperature and streamflow with the higher temporal resolution to develop a very precise relation among all the parameters. The decreased rainfall trends with increased trend in the temperature during southwest monsoon and winter season create a critical need to perform more detailed analysis to study the impacts on groundwater and surface water resources. Furthermore, this work can also be extended to study the impacts of projected land uses and future climatic projections over the streamflow to develop suitable policy and plans to maintain sustainability in available natural resources.

Acknowledgements. We acknowledge Dr. Arun Babu E, Assistant Professor, Centre for Water Resources, Anna University, Chennai, for his valuable guidance throughout the research period. The authors would also like to acknowledge the reviewers for their valuable guidance and suggestions to refine the manuscript.

\section{REFERENCES}

[1] Abeysingha, N. S., Singh, M., Sehgal, V. K., Kanna, M., Pathak, H. (2014): Trend analysis of Rainfall and Temperature of Districts of Gomati River Basin in North India. J. Agri. Phy 14: 56-66.

[2] Abeysingha, N., Singh, M., Sehgal, V. K., Khanna, M. (2016): Analysis of trends in streamflow and its linkages with rainfall and anthropogenic factors in Gomati River basin of North India. - Theoretical and Applied Climatology 123(3-4): 785-799. 
[3] Abeysingha, N. S., Jayasekara, J. M. N. S., Meegastenna, T. J. (2017): Streamflow trends in up and midstream of Kirindi Oya river basin in Srilanka and its linkages to rainfall. Maussam 68(1): 99-110.

[4] Ahmad, I., Tang, D., Wang, T. F., Wang, M., Wagan, B. (2015): Precipitation trends over time using Mann-Kendall and Spearman's rho tests in Swat river basin, Pakistan. Advances in Meteorology, Article ID 431860.

[5] Anand, J., Gosain, A. K., Khosa, R., Srinivasan, R. (2018): Regional scale hydrologic modelling for prediction of Water balance, analysis of trends in streamflow and variations in streamflow: The case study of the Ganga river basin. - Journal of Hydrology: Regional studies 16: 32-53.

[6] Anie John, S., Brema, J. (2018): Rainfall trend analysis by Mann-Kendall test for Vamanapuram River Basin, Kerala. - International Journal of Civil Engineering and Technology 9(13): 1549-1556.

[7] Arthi, B., Manikandan, N., Narayanan, M. (2014): Trend analysis of Rainfall and Frequency of rainy days over Coimbatore. - Mausam 65(3): 379-384.

[8] Chakraborty, S., Pandey, R. P., Chaube, U. C., Mishra, S. (2013): Trend and Variability analysis of rainfall series at Seonath River Basin, Chhattisgarh (India). - International Journal of Applies sciences and Engineering research 2.

[9] Chand, M. B., Bhattarai, B. C., Baral, P., Pradhananga, N. S. (2019): Trend analysis of Temperature data for Narayani River Basin, Nepal. - Sci 1(1): 21.

[10] Gautam, M. R., Acharya, K. (2012): Streamflow trends in Nepal. - Hydrological Sciences Journal 57(2): 344-357.

[11] Gedefaw, M., Wang, H., Song, X., Yan, D. M., Dong, G. Q., Wang, J. W., Girma, A., Aijaz Ali, B., Batsuren, D., Abiyu, A., Qin, T. L. (2018): Trend analysis of Climatic and Hydrological Variables in the Awash River basin, Ethiopia. - Water 10: 1554.

[12] Institute for Water studies. (2015): Report on Micro level Reappraisal study of Tamiraparani River basin. - Vol. 1, Public Works Department, Tamil Nadu.

[13] Islam, S., Sikder, B. (2012): Hydrological Characteristics Analysis of Surma River in North-eastern Bangladesh: A Quantitative approach. - Daffodil International University, Journal of Science and Technology 11(2): 39-47.

[14] Jain, S. K., Kumar, V. (2012): Trend analysis of Rainfall and Temperature data for India. - Current science 102(1): 37.

[15] Jain, S. K., Nayak, P. C., Singh, Y., Chandniha, S. K. (2017): Trends in rainfall and peak flows for some river basins in India. - Current science 112(8).

[16] Javari, M. (2017): Trend Analysis of Rainfall over Atrak River basin, Iran. - International journal of Applied Environmental Sciences 12(7): 1411-1448.

[17] Jayadas, A., Ambujam, N. K. (2019): Observed trends in indices for daily rainfall extremes specific to the agriculture sector in Lower Vellar River sub-basin, India Extreme rainfall trends over Lower Vellar sub-basin. - J. Earth Syst. Sci. 128(3): 1-15.

[18] Jayawardene, H., Jayawardene, D., Sonnadara, D. (2015): Interannual Variability of Precipitation in Sri Lanka. - Journal of National Science Foundation of Srilanka 43(1): 75-82.

[19] Kendall, M. G. (1995): Rank correlation methods. - Hafner Publishing Co., New York.

[20] Khavse, R., Deshmukh, R., Manikandan, N., Chaudhary, J. L., Kaushik, D. (2015): Statistical Analysis of Temperature and Rainfall Trend in Raipur District of Chhattisgarh. - Current World Environment 10(1): 305-312.

[21] Mann, H. B. (1945): Non-parametric tests against trend. - Econometrica 3: 245-259.

[22] Mondal, A., Kundu, S., Mukhopadhyay, A. (2012): Rainfall trend analysis by MannKendall test: a case study of north-eastern part of Cuttack district, Orissa. - International Journal of Geology, Earth and Environmental sciences 2(1): 70-78.

[23] Naidu, C. V., Durgalakshmi, K., Muni Krishna, K., Ramalingeshwara Rao, S., Sathyanarayana, G. C., Lakshminarayana, P., Malleswara Rao, L. (2009): Is summer 
monsoon rainfall decreasing over India in the global Warming era? - J. Geophys. Res. 114: D24108. http://dx.doi.org/10.1029/2008JD011288.

[24] Naidu, C. V., Dharma Raju, A., Satyanarayana, G. Ch., Vinay Kumar, P., Chiranjeevi, G., Suchitra, P. (2015): An observational evidence of decrease of Indian summer monsoon rainfall in the recent three decades of global warming era. - Global and Planetary Change 127: 91-102.

[25] Nouri, M., Homaee, M., Bannayan, M. (2017): Quantitative trend, sensitivity and contribution analysis of reference evapotranspiration in some arid environments under climate change. - Water resources Management 31(7): 2207.

[26] Nune, R., George, B. A., Teluguntla, P., Western, A. W. (2012): Relating trends in Stream flow to anthropogenic influences: a case study of Himayat Sagar catchment, India. - Hydrol Earth Syst Sci. Doi: 10.5194/hessd-9-9295.

[27] Ozgur, K. I. S. I., Okan, E. R. A. Y., Cihan, M. E. R. T. (2017): Trend analysis of long term temperatures in Tbilisi, Georgia. - Journal of Technical Science \& Technologies 5(2): 59.

[28] Palaniswami, S., Muthiah, K. (2018): Change point detection and Trend analysis of Rainfall and Temperature series over the Vellar river basin. - Pol.J.Environ.Stud. 27(4): 1673-1681.

[29] Panda, D. K., Kumar, A., Ghosh, S., Mohanty, R. K. (2013): Streamflow trends in the Mahanadi river basin (India); linkages to tropical climate variability. - J. Hydrol 495: 135-149.

[30] Panda, R. K., Singh, G. (2016): Analysis of trend and Variability in the Mid-Mahanadi river basin of Eastern India. - International scholarly and scientific Research \& Innovation 10(6).

[31] Punyawardena, B. V. R., Premalal, K. H. M. S. (2013): Do trends in extreme positive rainfall anomalies in the central highlands of Srilanka Exist? - Annals of Sri Lanka department of Agriculture 15: 1-12.

[32] Raghunath, H. M. (2006): Hydrology: principles, analysis and design. - New Delhi: New Age International.

[33] Samo, S. R., Bhatti, N., Saand, A., Keerio, M. A., Bangwar, D. K. (2017): Temporal analysis of Temperature and precipitation trends in Shaheed Benazir Abad Sindh, Pakistan. - Engineering technology and Applied Science research 7(6): 2171-2176.

[34] Sen, P. K. (1968): Estimates of the regression coefficient based on Kendall's tau. - J. Am. Stat. Assoc. 63: 1379-1389.

[35] Sharannya, T. M., Mudbhatkal, A., Mahesha, A. (2018): Assessing climate change impacts on river hydrology- A case study in the Western Ghats of India. - J. Earth syst. Sci. 127: 78.

[36] Sharif, M., Archer, D. R., Fowler, H. J., Forsythe, N. (2013): Trends in timing and magnitude of flow in the Upper Indus Basin. - Hydrol. Earth Syst. Sci. 17: 1503-1516.

[37] Sharma, G. K., Chaudhary, J. L. (2014): Time trends in temperature of Bastar plateau agro climatic zones of Chhattisgarh. - Mausam 65(1): 29-36.

[38] Sharma, S., Singh, P. K. (2019): Spatial trends in rainfall seasonality: a case study in Jharkhand, India. - Weather 70(1).

[39] Silva, R., Santos, C., Moreira, M., Corte-Real, J., Silva, V., Medeiros, I. (2015): Rainfall and river flow trends using Mann-Kendall and Sen's slope estimator statistical test in Cobras River Basin. - Nat hazards 77(2): 1205-1221.

[40] Sridhar, S. I., Raviraj, A. (2017): Statistical trend analysis of rainfall in Amaravathi River basin using Mann-Kendall. - Current World Environment 12(1): 89-96.

[41] Taxak, A. K., Murumkumar, A. R., Arya, D. S. (2014): Long term spatial and temporal trends and Homogeneity analysis in Wainganga basin, Central India. - Weather and Climate Extremes 4: 50-61. 
[42] Theil, H. (1950): A rank - invariant method of linear and polynomial regression analysis. - Part I, II, III, In Proceedings of Koninalijke Nederlandse Akademie van Weinenschatpen A.53, 386, 512, 1397.

[43] Vidhya, R., Arulkumar, T. (2017): Geospatial Assessment Of Land Use and Climate change impacts on Hydrology of the Tamiraparani river basin, India. - Ecology, Environment and Conservation Paper 23(2): 992-1002.

[44] Yadav, R., Tripathi, S. K., Pranuthi, G., Dubey, S. K. (2014): Trend analysis by MannKendall test for precipitation and temperature for thirteen districts of Uttarakhand. Journal of Agrometerology 16(2): 164-171.

[45] Zarenistanak, M., Dhorde, A. G., Kripalani, R. H. (2014): Trend analysis and Change point detection of annual and seasonal precipitation and temperature series over southwest Iran. - Journal of earth system science 123(2): 281. 